\title{
Positive Correlation Between Learning Motivation and Student Learning Outcomes in Physics Subjects Momentum and Impulse Materials
}

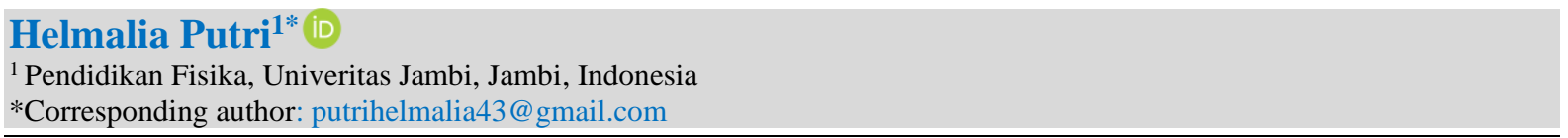

\begin{abstract}
Abstrak
Motivasi merupakan salah satu dari beberapa hal yang menentukan keberhasilan belajar siswa. Tanpa adanya motivasi, proses belajar sulit untuk mencapai keberhasilan yang optimal. Tujuan dari penelitian ini adalah untuk mengetahui pengaruh pembelajaran motivasi terhadap hasil belajar siswa kelas XI. Jenis penelitian ini adalah penelitian kuantitatif. Instrumen yang digunakan untuk mengumpulkan data pada penelitian ini adalah angket minat belajar dan tes soal pilihan ganda. Teknik analisis data uji prasyarat yang dilakukan diantaranya uji korelasi dengan bantuan software SPSS 21. Teknik pengumpulan data dalam penelitian ini digunakan soal dengan 30 butir soal dengan materi momentum dan impuls berganti secara teratur. Populasi penelitian ini adalah siswa kelas XI. Metode yang digunakan dalam penelitian ini adalah Deskriptif Statistik. Uji persyaratan analisis data yang digunakan adalah uji korelasi. Uji korelasi digunakan untuk menentukan seberapa kuat hubungan antara dua data apakah variable bebas mempunyai hubungan yang kuat terhadap variable terikat dengan kriteria pengambilan keputusan yaitu Sig. (2-tailed) < ayaitu 0,01. Berdasarkan hasil penelitian ini, menunjukkan bahwa terdapat pengaruh positif yang signifikan antara siswa motivasi belajar fisika siswa kelas XI terhadap hasil belajar pada materi momentum dan impuls.
\end{abstract}

Kata kunci: Learning Motivation, Learning Outcomes, Physics

\section{Abstract}

Motivation is one of several things that determine the success of student learning. Without motivation, the learning process is difficult to achieve optimal success. The purpose of this study was to determine the effect of learning motivation on student learning outcomes in class XI. This type of research is quantitative research. The instruments used to collect data in this study were a learning interest questionnaire and multiple choice questions. The prerequisite test data analysis techniques were carried out including the correlation test with the help of SPSS 21 software. The data collection technique in this study used questions with 30 questions with momentum and impulse material changing regularly. The population of this study were students of class XI. The method used in this research is descriptive statistics. The data analysis requirements test used was a correlation test. The correlation test is used to determine how strong the relationship between the two data is whether the independent variable has a strong relationship to the dependent variable with the decision-making criteria, namely Sig. (2-tailed) $<\alpha$ of 0.01 . Based on the results of this study, it shows that there is a significant positive influence between students' motivation to learn physics in class XI students on learning outcomes on momentum and impulse materials.

Keywords: Learning Motivation, Learning Outcomes, Physics

$\begin{array}{ll}\text { History: } & \text { Publisher: Undiksha Press } \\ \text { Received : May 22, } 2021 & \text { Licensed: This work is licensed under } \\ \text { Revised : May 23, } 2021 & \text { a Creative Commons Attribution 3.0 License } \\ \text { Accepted : August 04, } 2021 & \text { CC () () } \\ \text { Published : October 25, } 2021 & \text { SA }\end{array}$

\section{INTRODUCTION}

Education is a process for acquiring and imparting skills that are carried out by students. Education itself has a goal to develop the potential contained in students, so that they can think critically and creatively (Asmarani \& Idrus, 2017; Astalini. et al., 2019). Education is a process in order to influence students to be able to adapt as best as possible to their environment, so that it will cause changes in themselves. School is one of the places where the educational process takes place through teaching and learning activities between teachers and students (Oktaviana et al., 2016; Wijayanti \& Wasitohadi, 2015). Natural Sciences (IPA) is a science that studies the entire universe and its contents (Hairida, 2016; Parmiti et al., 2021). However, science has limited knowledge, namely things that can only 
be understood by the senses (sight, hearing, taste, touch and touch) (Eliyana, 2020; Rostikawati \& Permanasari, 2016). Physics is a branch of science that studies objects in nature physically and written down mathematically so that they can be understood by humans and used for the welfare of mankind (Puspitasari, 2019; Yusuf \& Wulan, 2015). Physics learning is a learning process that involves students in studying nature and its symptoms through a series of scientific processes that are built on the basis of scientific attitudes to acquire and process knowledge, skills and attitudes in order to achieve certain learning goals (Priyantini et al., 2015; R. Z. Putri et al., 2017).

Physics is one of the subjects that has been introduced to students from elementary school to college (Darmaji et al., 2019; Lestari \& Diana, 2018). However, in reality physics lessons are less attractive to students in general, because they are considered difficult, so the physics learning process is not as expected. One of the problems students have in learning in class is the lack of understanding of the concept of the subject matter. This difficulty then caused the students' lack of interest in physics. This causes the activity of students in participating in physics learning in class to be low. The physics learning process carried out by students as learning subjects is of course influenced by several factors, both factors from students and factors from the environment (Pasaribu et al., 2017; Simatupang et al., 2017). Physics is part of science, so students' attitudes towards Physics subjects are also included in students' attitudes towards science (R. M. Putri et al., 2019; Wahyudi \& Lestari, 2019). Based on the results of observations of student attitudes at SMA Negeri 5 Muaro Jambi during the learning process in class, it can be seen that there are positive and negative attitudes towards physics subjects. The positive attitude of students towards physics subjects is seen when students are enthusiastic during the learning process, students are active to ask and answer questions given by the teacher, especially during group discussions in class, the positive attitude of students is the interaction between students and teachers in the learning process. While the negative attitude of students towards physics subjects is seen when students are not active in the learning process, students are silent from the beginning of the learning process until the end of learning, and students talk to friends next to them during the learning process group discussions take place in class (Astalini. et al., 2018; Hardian et al., 2018).

Interest in learning is a desire or willingness accompanied by intentional attention and activity which ultimately gives birth to pleasure in changing behavior, both in the form of knowledge, attitudes, and skills (Aprinawati, 2017; Supriyono, 2018). Explain that one's enjoyment of physics will also affect learning achievement. This is because there is a relationship between attitude and learning achievement. Learning attitude is an important factor to determine student achievement. Students who prefer a subject will get good grades on that subject (Jufrida, 2019; Tamayanti et al., 2019). Fun in learning physics is the love of students to learn physics which is upheld by high curiosity (Astalini. et al., 2018). Physics will be easily accepted if students' attitudes are positive in involving strategies to solve problems in it. Weak motivation to study physics due to a lack of understanding of the nature, benefits, beauty and employment that can result from studying physics (Aminoto et al., 2019). So that learning physics feels more fun, then the benefits of studying physics need to be understood. To face any obstacles or difficulties while studying physics, learning motivation is the first capital.

Motivation is an impulse contained in a person to try to make changes in behavior for the better in meeting their needs (Hakim \& Windayana, 2016). Motivation is a desire that arises in oneself to do something (Suprihatin, 2015). A person who has a strong desire will usually work hard to achieve his goals. Extrinsic motivation is motivation that arises from outside but does not always have a relationship with learning activities (Sulistiari, 2018; Yulianingsih et al., 2020). Extrinsic motivation forms such as learning to fulfill obligations, avoiding punishment, getting prizes, increasing prestige, getting praise and learning for the 
demands of the desired position. While intrinsic motivation is learning motivation that arises purely from oneself to be able to solve a problem or achieve a goal. Motivasi dianggap penting dalam upaya belajar dan pembelajaran dilihat dari segi fungsi dan nilainya atau manfaatnya (Primadona et al., 2018). One of the physiological factors which include learning motivation, interest in learning, and study habits. A student who has high motivation and interest will carry out the duties of the teacher no matter how heavy the task is (Jufrida, 2019).

One of the efforts so that students are not passive during the learning process in class so that one of the objectives of learning physics can be achieved is to choose or develop their own appropriate teaching materials for students (Sari et al., 2017). So that it can motivate students to be able to follow the learning well. Students will be motivated to learn and engage in the learning process in a positive attitude towards physics, and vice versa. They are activated when individuals face unfamiliar problems, uncertainties, questions, or dilemmas. Therefore, students who have a positive attitude towards physics will increase and have the enthusiasm to learn physics. Students who like to study physics will have good analytical thinking skills (Darmaji, 2019). Student participation is very important in the implementation of the learning process in the classroom (Khodijah et al., 2016). With increasing student participation, student achievement will also increase. The urgency of this research is very important because in this study it was only carried out at SMA Negeri 5 Jambi City which was related to learning motivation on student learning outcomes. The gap in this study is found in research that covers the whole of the results of the filled student observation questionnaire. This research is in line with research which explains that the success of the learning process can be seen from learning outcomes where learning outcomes are influenced by good attitudes and motivation of students (Astalini, 2019). In a study, an assessment is needed to determine the development, progress, and learning outcomes of students during the learning of the educational program (Basuki, F et al., 2019).

Learning outcomes are the realization of the achievement of educational goals, so that the measured learning outcomes are highly dependent on the educational goals (Arrasyid et al., 2017; Kurnia et al., 2016). Learning outcomes are an achievement achieved by someone in following the learning process which can be measured from the results of the exercise or test taken from the material that has been delivered (Pasaribu et al., 2017; Saputra et al., 2019; Utami et al., 2017). Student learning outcomes will be optimal if students are motivated in learning. Learning motivation has a significant relationship with learning outcomes obtained by students (Saputra et al., 2019). Therefore, it would be better if in delivering learning materials the teacher paid attention to the learning motivation of each student. The purpose of this study is to see how the relationship between the student's motivation for physics subjects on momentum and impulse material at SMA Negeri 5 Jambi City in class XI MIPA 6. This study focuses on the relationship between learning motivation and student learning outcomes. This research was conducted by taking samples from the students of SMA Negeri 5 Jambi City in class XI MIPA 6 through questionnaires and test instruments. Therefore, this study aims to determine whether there is a relationship between student motivation and learning outcomes obtained by means of product moment correlation test.

\section{METHODS}

The type of research used is quantitative research with a descriptive approach. Descriptive research is collecting data based on the factors that support the object of research, then analyze these factors to look for their role. This research was conducted at SMA Negeri 5 Jambi City with a total population of 30 students in class XI MIPA 6, with the number of 
samples taken as many as 27 students. This research was conducted from February to March 2021 at SMA Negeri 5 Jambi City in class XI IPA 3 for the academic year 2020-2021 on momentum and impulse material and learning motivation for students. The subjects of this research are students of SMA Negeri 5 Jambi city class XI MIPA 6 academic year 20202021. The data collection technique used in this study was a questionnaire and test instrument. This study used a questionnaire that was carried out online using a cellphone or laptop where when doing research at that time we were still prohibited from entering students due to the covid 19 season. Questionnaire technique was used to collect data on student learning attitudes. The research instrument used includes a questionnaire for student learning attitudes which consists of 4 answer criteria, namely SS: Strongly Agree, S: Agree, TS: Disagree, STS: Strongly Disagree. The test consists of 25 questions in the form of multiple choice. The function of the test in research is as a measuring tool for student learning outcomes in the cognitive domain.

In this case, to determine the level of student learning outcomes in physics subjects. The data obtained were analyzed using descriptive statistical techniques. Descriptive statistics are descriptions or presentations of large numbers in this case in the form of summary frequencies, e.g. mean, maximum and minimum. The procedures in this study are a) administering a research permit to the party concerned, b) determining the research subject, c) taking research data using test instruments that are distributed to students, and d) then the data obtained is processed and analyzed using SPSS data processing software. This research was conducted at SMA Negeri 5 Jambi City with a predetermined procedure.

\section{RESULTS AND DISCUSSION}

\section{Results}

\section{Correlation Test}

The correlation test is used to determine how strong the relationship between the two data is whether the independent variable has a strong relationship to the dependent variable with the decision-making criteria, namely Sig. (2-tailed) $<\alpha$ of 0,01 . The results of the correlation test are presented in Table 1.

Table 1. Correlation Test Results

\begin{tabular}{|c|c|c|c|}
\hline & & $\begin{array}{c}\text { Learning } \\
\text { Motivation }\end{array}$ & $\begin{array}{l}\text { Learning } \\
\text { Outcomes }\end{array}$ \\
\hline Learning & Pearson & 1 & 0.912 \\
\hline \multirow{3}{*}{ Motivation } & Correlation & & \\
\hline & Sig. (2-tailed) & & 0.000 \\
\hline & $\mathrm{N}$ & 27 & 27 \\
\hline \multirow[t]{4}{*}{ Learning Outcomes } & Pearson & 0.912 & 1 \\
\hline & Correlation & & \\
\hline & Sig. (2-tailed) & 0.000 & \\
\hline & $\mathrm{N}$ & 27 & 27 \\
\hline
\end{tabular}

\section{Discussion}

The correlation in this study analyzed the indicators: [1] student interest in learning [2] test results of physics learning material momentum and impulse. Based on Table 1, it can be seen that the relationship between motivation and student learning outcomes obtained the value of Sig. (2-tailed) of 0.000 with a Pearson correlation of 0.912 , then $\mathrm{H} 0$ is rejected or it can be said that there is a positive and significant relationship between motivation and physics learning outcomes for class XI MIPA 6 at SMA Negeri Jambi City. From the 
research results obtained, learning motivation has a positive and significant relationship to learning outcomes. Therefore, it would be better for a teacher to be able to make physics a favourite subject, so that students have a better view of physics. One solution to increase student activity, interest and attention in the learning process is to condition students to be able to learn actively by sharing information with their friends. So that it will encourage students to be more enthusiastic and motivated in learning, so that student learning outcomes are even better.

Interest in learning is a desire or willingness accompanied by intentional attention and activity which ultimately gives birth to pleasure in changing behavior, both in the form of knowledge, attitudes, and skills (Aprinawati, 2017; Supriyono, 2018). Explain that one's enjoyment in physics will also affect learning achievement. This is because there is a relationship between attitude and learning achievement. Learning attitude is an important factor to determine student achievement. Students who prefer a subject will get good grades on that subject (Jufrida, 2019; Tamayanti et al., 2019). Fun in learning physics is the love of students to learn physics which is upheld by high curiosity (Astalini. et al., 2018). Physics will be easily accepted if students' attitudes are positive in involving strategies to solve problems in it. Weak motivation to study physics due to a lack of understanding of the nature, benefits, beauty and employment that can result from studying physics (Aminoto et al., 2019). So that learning physics feels more fun, then the benefits of studying physics need to be understood. To face any obstacles or difficulties while studying physics, learning motivation is the first capital.

Motivation is an impulse contained in a person to try to make changes in behavior for the better in meeting their needs (Hakim \& Windayana, 2016). Motivation is a desire that arises in oneself to do something (Suprihatin, 2015). A person who has a strong desire will usually work hard to achieve his goals. Extrinsic motivation is motivation that arises from outside but does not always have a relationship with learning activities (Sulistiari, 2018; Yulianingsih et al., 2020). Forms of extrinsic motivation such as learning to fulfill obligations, avoiding punishment, getting rewards, increasing prestige, getting praise and learning for the demands of the desired position. While intrinsic motivation is learning motivation that arises purely from oneself to be able to solve a problem or achieve a goal. Motivation is considered important in learning and learning efforts in terms of its function and value or benefits (Primadona et al., 2018). One of the physiological factors which include learning motivation, interest in learning, and study habits. A student who has high motivation and interest will carry out the duties of the teacher no matter how heavy the task is (Jufrida, 2019).

One of the efforts so that students are not passive during the learning process in class so that one of the objectives of learning physics can be achieved is to choose or develop their own appropriate teaching materials for students (Sari et al., 2017). So that it can motivate students to be able to follow the learning well. Students will have the motivation to learn and engage in the learning process in a positive attitude towards physics, and vice versa. They are activated when individuals face unfamiliar problems, uncertainties, questions, or dilemmas. Therefore, students who have a positive attitude towards physics will increase and have the enthusiasm to learn physics. Students who like to study physics will have good analytical thinking skills (Darmaji, 2019). Student participation is very important in the implementation of the learning process in the classroom (Khodijah et al., 2016). With the increase in student participation, student achievement will also increase. The urgency of this research is very important because in this study it was only carried out at SMA Negeri 5 Jambi City which was related to learning motivation on student learning outcomes. The gap in this research is in the research that covers the entire result of the student observation questionnaire that is filled in. This research is in line with research which explains that the success of the learning 
process can be seen from learning outcomes where learning outcomes are influenced by good attitudes and motivation of students (Astalini, 2019). In a study, an assessment is needed to determine the development, progress, and learning outcomes of students during the learning of the educational program (Basuki, F et al., 2019).

Learning outcomes are the realization of the achievement of educational goals, so that the measured learning outcomes are highly dependent on the educational goals (Arrasyid et al., 2017; Kurnia et al., 2016). Learning outcomes are an achievement achieved by someone in following the learning process which can be measured from the results of the exercise or test taken from the material that has been delivered (Pasaribu et al., 2017; Saputra et al., 2019; Utami et al., 2017). Student learning outcomes will be optimal if students are motivated in learning. Learning motivation has a significant relationship with learning outcomes obtained by students (Saputra et al., 2019). Therefore, it would be better if in delivering learning materials the teacher paid attention to the learning motivation of each student. Based on the results of research on the relationship between learning motivation and learning outcomes in class XI IPA 6 SMA Negeri 5 Jambi City. For students, it is expected that students can increase learning motivation in order to increase their scores on student learning test results. And teachers in the field of physics are expected to be able to create fun physics subjects by providing a variety of interesting learning methods so that there is an increase in student learning motivation.

\section{CONCLUSION}

There is a positive relationship between learning motivation and physics learning outcomes. This is because motivation is something that plays an important role in learning, especially learning physics. This is because learning motivation is a desire that arises in oneself to do something. The higher the motivation to learn, the higher the learning outcomes and the lower the motivation, the lower the learning outcomes. One solution to increase student activity, interest and attention in the learning process is to condition students to be able to learn actively by sharing information with their friends.

\section{REFERENCES}

Aminoto, T., Dani, R., \& Yuversa, E. (2019). Pengembangan Termometer Gas Sebagai Alat Peraga Pembelajaran Pokok Bahasan Skala Suhu Mutlak. Jurnal EduFisika, 4(2), 4855. https://doi.org/10.22437/edufisika.v4i02.7636.

Aprinawati, I. (2017). Penggunaan Media Gambar Seri Untuk Meningkatkan Kemampuan Berbicara Anak Usia Dini. Obsesi: Jurnal Pendidikan Anak Usia Dini, 1(1), 12-18.

Arrasyid, H., Jufrida., \& Darmaji. (2017). Aktivitas Dan Hasil Belajar Siswa Dengan Menggunakan Model Pembelajaran Problem Based Learning Berbantuan Lembar Kerja Siswa Pada Materi Kalor Dan Perpindahannya Kelas X SMA PGRI 2 Jambi. Jurnal Edufisika, 2(2), 68-80. https://doi.org/10.22437/edufisika.v5i02.10886.

Asmarani, A., \& Idrus, I. (2017). Peningkatkan Sikap Ilmiah Siswa Melalui Penerapan Model Discovery Learning. Jurnal Pendidikan Dan Pembelajaran Biologi, 1(1), 16-22.

Astalini., Kurniawan, D. A., Perdana, R., \& Pathoni, H. (2019). Identifikasi sikap peserta didik terhadap mata pelajaran fisika di Sekolah Menengah Atas Negeri 5 Kota Jambi. Unnes Physics Education Jurnal, 8(1), 1-14. https://doi.org/10.15294/upej.v8i1.29510.

Astalini., Kurniawan, Dwi. A., S., \& Umaryanti. (2018). Sikap Siswa Terhadap Pelajaran Fisika Di SMAN Kabupaten Batanghari. Jurnal Ilmu Pendidikan Fisika, 3(2), 59-64. https://doi.org/10.26737/jipf.v3i2.694. 
Astalini. (2019). Motivation and Attitude of Students on Physics Subject in the Middle School in Indonesia. International Education Studies, 12(9), 15-26. https://doi.org/10.5539/ies.v12n9p15.

Basuki, F, R., Jufrida., Kurniawan, W., Devi, I. P., \& Fitaloka, O. (2019). Tes Keterampilan Proses Sains: Multiple Choice Format. Jurnal Pendidikan Sains(JPS), 7(2), 101-111. https://doi.org/10.22437/edufisika.v5i02.10886.

Cohen, L., Manion, L., Lecturer, P., Morrison, K., \& Lecturer, S. (2007). Research Methods in Education.

Darmaji. (2019). A study relationship attitude toward physics, motivation, and character discipline students senior high school, in Indonesia. International Journal of Learning and Teaching, 11(3), 99-109. https://doi.org/10.18844/ijlt.v11i3.4207.

Darmaji, D., Kurniawan, D. A., Astalini, A., \& Nasih, N. R. (2019). Persepsi Mahasiswa pada Penuntun Praktikum Fisika Dasar II Berbasis Mobile Learning. Jurnal Pendidikan: Teori, Penelitian, Dan Pengembangan, 4(4), 516-523.

Eliyana, E. (2020). Analisis Keterampilan Proses Sains Siswa Belajar IPA Materi Tumbuhan Hijau Pada Siswa Kelas V SDN 3 Panjerejo di Masa Pandemi Covid-19. EDUPROXIMA : Jurnal Ilmiah Pendidikan IPA, 2(2), 87. https://doi.org/10.29100/eduproxima.v2i2.1628.

Hairida, H. (2016). The Effectiveness Using Inquiry Based Natural Science Module With Authentic Assessment to Improve The Critical Thinking and Inquiry Skills of Junior High School Students. Jurnal Pendidikan IPA Indonesia, 5(2). https://journal.unnes.ac.id/nju/index.php/jpii/article/view/7681/5453.

Hakim, A. R., \& Windayana, H. (2016). Pengaruh penggunaan multimedia interaktif meningkatkan hasil belajar siswa SD. EduHumaniora | Jurnal Pendidikan Dasar Kampus Cibiru, 4(2), 1-13.

Hardian, K., Astalini, \& Kurniawan, D, A. (2018). Sikap Siswa Terhadap Mata Pelajaran Fisika Di SMA Negeri 5 Kota Jambi. Jurnal Edufisika, 3(2), 1-12. https://doi.org/10.22437/edufisika.v3i02.4522.

Jufrida. (2019). Students' attitude and motivation in mathematical physics. International Journal of Evaluation and Research in Education (IJERE), 8(3), 401-408. https://doi.org/10.11591/ijere.v8i3.20253.

Khodijah, Dwinda, N., Hendri, M., \& Darmaji. (2016). Upaya Meningkatkan Partisipasi Dan Hasil Belajar Dengan Menggunakan Model Pembelajaran Kooperatif Tipe Think Pair Share Di Kelas XI MIA7 SMAN 1 Muaro Jambi. Jurnal EduFisika, 1(2), 46-54. https://doi.org/10.22437/edufisika.v1i2.3429.

Kurnia, N., Hendri, M., \& Pathoni, H. (2016). Hubungan persepsi dengan hasil belajar fisika siswa kelas X MIA di SMA Negeri 4 Kota Jambi dan SMA Negeri 11 Kota Jambi. Jurnal Edufisika, 1(2), 1-12. https://doi.org/10.22437/edufisika.v1i2.3430.

Lestari, M. Y., \& Diana, N. (2018). Keterampilan Proses Sains (KPS) Pada Pelaksanaan Praktikum Fisika Dasar I. Indonesian Journal of Science and Mathematics Education, 1(1), 49-54. https://doi.org/10.24042/ijsme.v1i1.2474.

Oktaviana, D., Jufrida., \& Darmaji. (2016). Penerapan RPP Berbasis Multiple Intelligences Untuk Meningkatkan Aktivitas Dan Hasil Belajar Fisika Siswa Pada Materi Kalor Dan Perpindahan Kalor Kelas X MIA 4 SMA Negeri 3 Kota Jambi. Jurnal EduFisika, 1(1), 7-12. https://doi.org/10.22437/edufisika.v1i1.2957.

Parmiti, D., Rediani, N., Antara, I., \& Jayadiningrat, M. (2021). The Effectiveness of Local Culture-Integrated Science Learning Through Project Based Assessment on Scientific Attitudes and Science Process Skills of Elementary School Students. Jurnal Pendidikan IPA Indonesia, 10(3), 439-446. https://doi.org/10.15294/jpii.v10i3.31301.

Pasaribu, Dewi, S., Hendri, M., \& Susanti, N. (2017). Upaya Meningkatkan Minat dan Hasil 
Belajar Fisika Siswa Dengan Menggunakan Model Pembelajaran Talking Stick Pada Materi Listrik Dinamis Di Kelas X SMAN 10 Muaro Jambi. Jurnal EduFisika, 2(1), 61-69. https://doi.org/10.22437/edufisika.v2i01.4043.

Prabowo, A., \& Heriyanto. (2013). Analisis Pemanfaatan Buku Elektronik (E-BOOK) Oleh Pemustaka di Perpustakaan SMA Negeri 1 Semarang. Jurnal Ilmu Perpustakaan, 2(2), $\quad$ 1-9. https://www.academia.edu/26392333/Analisis_Pemanfaatan_Buku_Elektronik_E_Bo ok_Oleh_Pemustaka_DI_Perpustakaan_Sma_Negeri_1_Semarang.

Primadona, H., Nehru., \& Kurniawan, W. (2018). Perbandingan Motivasi Belajar Siswa Dengan Menggunakan Media Lectora Inspire dan Powerpoint Pada Materi Momentum Dan Impuls kelas X SMAN 3 Muaro Jambi. Jurnal EduFisika, 3(1), 4354. https://doi.org/10.22437/edufisika.v3i01.3956.

Priyantini, N. P. T., Sadia, I. ., \& Suastra, I. W. (2015). Pengembangan Perangkat Pembelajaran Fisika SMA Bermuatan Karakter dengan setting Model Sains Teknologi Masyarakat dan Lingkungan untuk Meningkatkan Karakter dan Keterampilan Berpikir Kreatif Siswa. Jurnal Pendidikan IPA, 5(1). https://ejournalpasca.undiksha.ac.id/index.php/jurnal_ipa/article/view/1568/1224.

Puspitasari, A. D. (2019). Penerapan Media Pembelajaran Fisika Menggunakan Modul Cetak Dan Modul Elektronik Pada Siswa SMA. Jurnal Pendidikan Fisika, 7(1), 17-25. https://doi.org/10.24252/jpf.v7i1.7155.

Putri, R. M., Risdianto, E., \& Rohadi, N. (2019). Pengembangan Media Pembelajaran Interaktif Dengan Menggunakan Adobe Captivate Pada Materi Gerak Harmonik Sederhana. Jurnal Kumparan Fisika, 2(2), 113-120. https://doi.org/10.33369/jkf.2.2.113-120.

Putri, R. Z., Lesmono, A. ., \& Aristya, P. . (2017). Pengaruh Model Discovery Learning Terhadap Motivasi Belajar dan Hasil Belajar Fisika Siswa Man Bondowoso. Jurnal Pendidikan Fisika, 6(2), 168-174. https://doi.org/10.19184/jpf.v6i2.5017.

Rostikawati, D. A., \& Permanasari, A. (2016). Rekonstruksi Bahan Ajar Dengan Konteks Socio-Scientific Issues Pada Materi Zat Aditif Makanan Untuk Meningkatkan Literasi Sains Siswa. Jurnal Inovasi Pendidikan IPA, 2(2), 156-164. https://doi.org/10.21831/jipi.v2i2.8814.

Saputra, W. R., Hendri, M., \& Aminoto, T. (2019). Korelasi Motivasi Dan Hasil Belajar Ipa Siswa Kelas VIII Di Smp Negeri Se-Kecamatan Jambi Selatan. Jurnal Pendidikan Fisika, 4(2), 36-45. https://doi.org/10.22437/edufisika.v4i01.3996.

Sari, Putri, E. N., \& Nehru. (2017). Pengembangan Lembar Kerja Siswa (LKS) Berbasis Inkuiri Terbimbing Pada Materi Rangkaian Arus Searah Untuk Kelas XII SMA. Jurnal EduFisika, 2(1), 70-79. https://doi.org/10.22437/edufisika.v2i01.4044.

Simatupang, R. Y., Jufrida., \& Aminoto, T. (2017). Upaya Meningkatkan Aktivitas Dan Hasil Belajar Fisika Siswa Dengan Menggunakan Model Pembelajaran Inkuiri Tipe Guided Inquiry Di Kelas XI MIA 2 SMA Negeri 11 Kota Jambi. Artikel Ilmiah Jambi: Universitas Jambi. https://repository.unja.ac.id/1529/1/ARTIKEL ILMIAH Risna.pdf.

Sugiyono. (2014). Metode Penelitian Pendidikan Pendekatan Kuantitatif, Kualitatif, dan $R \& D$. Alfabeta.

Sulistiari. (2018). Pengaruh Motivasi, Tipe Belajar, Lingkungan Keluarga, dan Lingkungan Masyarakat Terhadap Hasil Belajar Siswa. Jurnal Pendidikan Ekonomi, Manajemen, Dan Keuangan, 2(1), 57-70. https://doi.org/10.2674 0/jpeka.v 2n1.p57-70.

Suprihatin, S. (2015). Upaya guru dalam meningkatkan motivasi belajar siswa. Jurnal Pendidikan Ekonomi UM Metro, 3(1), 73-82. https://ojs.fkip.ummetro.ac.id/index.php/ekonomi/article/view/144. 
Supriyono. (2018). Pentingnya Media Pembelajaran Untuk Meningkatkan Minat Belajar Siswa SD. Edustream: Jurnal Pendidikan Dasar, 2(1), 43-48. https://journal.unesa.ac.id/index.php/jpd/article/view/6262.

Tamayanti, P. A., Sujana, I. W., \& Wiarta, I. W. (2019). Kontribusi Sikap Disiplin Dan Motif Berkompetisi Terhadap Kompetensi Pengetahuan Ips Siswa Kelas Iv. Media Komunikasi FPIPS, 17(2), 89-99. https://doi.org/10.23887/mkfis.v17i2.22227.

Utami, Suci, A., Hendri, M., \& Darmaji. (2017). Hubungan Lingkungan Belajar Terhadap Hasil Belajar Fisika Kelas XI MIA SMAN 1 Muaro Jambi. Jurnal EduFisika, 2(2), 58-67. https://doi.org/10.22437/edufisika.v2i02.4544.

Wahyudi, W., \& Lestari, I. (2019). Pengaruh Modul Praktikum Optika Berbasis Inkuiri Terhadap Keterampilan Proses Sains dan Sikap Ilmiah Mahasiswa. Jurnal Pendidikan Fisika Dan Keilmuan (JPFK), 5(1), 33-44.

Wijayanti, R., \& Wasitohadi, W. (2015). Efektivitas Pembelajaran Value Clarification Technique (VCT) Berbantu Media Video Interaktif Ditinjau Dari Hasil Belajar Pkn. Satya Widya, 31(1), 54. https://doi.org/10.24246/j.sw.2015.v31.i1.p54-68.

Yulianingsih, W., Suhanadji, S., Nugroho, R., \& Mustakim, M. (2020). Keterlibatan Orangtua dalam Pendampingan Belajar Anak selama Masa Pandemi Covid-19. Jurnal Obsesi : Jurnal Pendidikan Anak Usia Dini, 5(2), 1138-1150. https://doi.org/10.31004/obsesi.v5i2.740.

Yusuf, M., \& Wulan, A. R. (2015). Penerapan Model Pembelajaran Discovery Learning Menggunakan Pembelajaran Tipe Shared dan Webbed untuk Meningkatkan Keterampilan Proses Sains. Jurnal Penelitian \& Pengembangan Pendidikan Fisika, 1(2), 19-26. https://doi.org/10.21009/1.01204. 